\title{
SISTEM INFORMASI FARMASI BERBASIS WEB MOBILE DENGAN FITUR DETEKSI KESALAHAN OBAT DALAM PENJUALAN OBAT PERACIKAN
}

\author{
${ }^{1}$ Herman Yuliansyah*, ${ }^{2}$ Ica Kurnia Hildayanti \\ 1Teknik Informatika, Universitas Ahmad Dahlan, Yogyakarta, Indonesia \\ 2Teknik Informatika, Universitas Ahmad Dahlan, Yogyakarta, Indonesia \\ e-mail: ${ }^{1}$ herman.yuliansyah@tif.uad.ac.id. ${ }^{2}$ icakurniahildayanti@gmail.com \\ *correspondence email
}

\begin{abstract}
Abstrak
Salah satu kegiatan di apotek adalah menjual resep atau non-resep. Kesalahan pengobatan dapat terjadi selama penjualan obat. Salah satu penyebab kesalahan pengobatan adalah kesalahan dalam pemberian resep obat. Dengan demikian, Sistem Informasi Farmasi memerlukan fitur yang dapat membantu dalam meminimalkan terjadinya kesalahan pengobatan. Metodologi dalam penelitian ini adalah observasi, wawancara dan studi literatur. Sistem informasi memiliki tiga tingkat pengguna: admin, pekerja gudang dan apoteker. Sistem informasi memiliki fitur deteksi kesalahan obat untuk memproses transaksi penjualan obat peracikan. Sistem informasi dapat menentukan dosis maksimum obat-obatan untuk senyawa dan sistem informasi yang dilengkapi dengan fitur pemberitahuan untuk menyesuaikan antara dosis dokter dan dosis maksimum yang harus diberikan kepada pasien. Hasil dari penelitian ini adalah Sistem Informasi Farmasi, yang memiliki fitur deteksi kesalahan obat, dapat mencegah kesalahan pengobatan karena sistem akan memberikan pemberitahuan untuk menyesuaikan antara dosis dokter dan dosis maksimum.
\end{abstract}

Kata Kunci: Sistem Informasi Farmasi, Obat Resep, Kesalahan Obat, aplikasi berbasis web

\section{PENDAHULUAN}

Ketersediaan obat-obatan baik resep maupun non-resep, dan peralatan medis adalah kegiatan utama di bidang farmasi. Kegiatan lain adalah mengelola obat, stok obat, penetapan harga obat, pembelian obat, penjualan obat, dan laporan transaksi di apotek. Namun, penjualan obat resep dapat menyebabkan kesalahan pengobatan. Salah satu penyebabnya adalah kesalahan dalam dosis obat, terutama obat peracikan.

Berdasarkan Surat Keputusan Menteri Kesehatan Republik Indonesia, Nomor 1027 / Menkes / SK / IX / 2004 layanan farmasi standar, menjelaskan bahwa definisi kesalahan pengobatan adalah terjadinya pasien yang merugikan, akibat dari penggunaan obat selama perawatan, yang seharusnya bisa dicegah [1].

Beberapa penyebab kesalahan pengobatan adalah kesalahan resep, kesalahan dalam dosis penulisan, resep tidak jelas atau tidak lengkap dan administrasi tidak lengkap. Kesalahan pengeluaran dapat terjadi ketika membaca resep Look Alike Sound Alike (LASA), jumlah kesalahan obat, obat tidak sesuai dengan resep, dosis yang diberikan salah dan membentuk kesalahan [2].

Resep yang ditulis oleh Dokter yang memuat ketentuan farmasi dan apoteker tidak dapat mengingat semua istilah ini, terutama apoteker baru. Jadi apoteker akan melayani pasien, harus membuka buku-buku ISO (Informasi Spesialite Obat) Indonesia. Jadi, apoteker membutuhkan sistem yang dapat memproses penjualan obat resep, terutama ramuan. Sistem ini akan membantu mengurangi kesalahan pengobatan dan membantu proses penghitungan harga pada penjualan obat secara rinci, sehingga 
kwitansi penjualan bahwa harus ada layanan resep, biaya embalase (biaya kertas kado untuk obat pribadi, botol, dll.) mungkin sudah termasuk dalam harga obat.

Makalah ini akan fokus pada perancangan sistem informasi farmasi berbasis web dengan fitur pendeteksian obat dalam penjualan obat peracikan. Sistem ini diharapkan dapat membantu apoteker dalam proses penjualan obat dan memberikan peringatan jika terjadi kesalahan pengobatan, karena kesalahan pengobatan dapat berdampak buruk bagi pasien.

\section{STUDI LITERATUR}

\section{Penelitian Terdahulu}

Tri Murwanto, dkk telah melakukan penelitian tentang sistem informasi farmasi terintegrasi dengan sistem resep yang dapat memberikan informasi untuk administrator, dokter, apoteker, pegawai farmasi, dan anggota farmasi melalui browser web, dan untuk membantu manajemen data farmasi [3]. Studi lain yang dilakukan oleh Muhammad Azhar Irwansyah, et al p tentang perancangan sistem informasi manajemen farmasi berdasarkan server klien untuk membantu mengelola data kinerja apotek apotek [4]. Cecelia Lupi Hepyan, dkk melakukan penelitian tentang desain aplikasi penjualan obat di apotek sebagai upaya untuk menghasilkan informasi mengenai penjualan obat yang akurat, dan memberikan laporan penjualan dengan mudah dan tepat waktu [5]. Hanik Mujiati, dkk melakukan penelitian tentang sistem informasi persediaan obat di apotek, untuk membantu apoteker dalam melayani pemrosesan transaksi dan memeriksa persediaan obat [6]. Nurdiasyah, dkk melakukan penelitian tentang pengembangan sistem informasi berbasis web untuk memfasilitasi pemrosesan data apotek, seperti data obat, data penjualan obat, pembuatan kwitansi, pembuatan laporan kepada pimpinan, dan untuk memudahkan proses pencarian data [7].

\section{Resep}

Resep adalah permintaan tertulis dari dokter, dokter gigi, dan dokter hewan kepada apoteker untuk menyediakan dan menyerahkan obat untuk pasien sesuai dengan peraturan [1].

\section{Mesin Peracikan}

Obat peracikan adalah obat yang dibuat dengan mencampur bahan aktif dan mengubah bentuk sediaan menjadi bentuk sediaan lainnya. Peracikan adalah serangkaian kegiatan persiapan, penimbangan, pencampuran, pengemasan dan pelabelan. Obat diformulasikan dan dicampur untuk memenuhi kebutuhan pasien tertentu, dalam hal ini pediatri dalam rangka memberikan obat yang tidak tersedia atau tidak sesuai dengan kriteria [8].

\section{Pediatri}

Pediatrik berasal dari kata Paedes = anak dan Iztrica = pengobatan. Kedokteran anak adalah anak-anak, tidak hanya merawat anak tetapi juga mencakup hal-hal yang lebih luas [9]. DM (dosis maksimum) adalah dosis maksimum untuk orang dewasa yang menggunakan oral, subkutan dan dubur. Perhitungan dosis untuk pediatri adalah sebagai berikut [10]:

4.1 Fried and Clark Formula (untuk anak yang kurang dari satu tahun)

$$
\frac{\text { age (month) }}{150} \times \text { DM adult }
$$

4.2 Young Formula (untuk anak usia 1-8 tahun)

$$
\frac{\text { age }(\text { year })}{\text { age }(\text { year })+12} \times D M \text { adult }
$$

4.3 Dilling Formula (untuk anak usia 8-20 tahun) 


$$
\begin{aligned}
& \qquad \frac{\text { age (year) }}{20} \times D M \text { adult... } \\
& \begin{array}{l}
\text { 4.4 Thermic Formula (dari berat) } \\
\frac{\text { body weight }}{70} \times D M \text { adult }
\end{array}
\end{aligned}
$$

\section{METODE PENELITIAN}

Metodologi dalam penelitian ini mengacu pada metode pengembangan perangkat lunak. Tahap analisis akan menghasilkan analisis kebutuhan pengguna dan persyaratan sistem, desain sistem dari aktivitas desain, data desain, dan desain antarmuka pengguna. Tahap implementasi akan mengembangkan aplikasi berbasis web menggunakan PHP Framework CodeIgniter. Pengujian sistem dilakukan oleh Black Box Test dan Pertanyaan Terbuka.

\section{HASIL DAN PEMBAHASAN}

Pada bagian ini akan dibagi menjadi beberapa tahapan yaitu analisis kebutuhan, perancangan sistem, implementasi sistem, pengujian sistem, dan pertanyaan terbuka.

\section{Kebutuhan Analisis}

1.1 Kebutuhan User

a. Sistem Pengguna (admin, petugas gudang dan apoteker) dapat masuk dan keluar sistem.

b. Administrator dapat mengelola data pengguna di Sistem Informasi Farmasi.

c. Administrator dapat melihat laporan seperti laporan penjualan, laporan stok, dan dapat mengunduh laporan jika diperlukan.

d. Petugas dapat mengelola data gudang dan pemasok obat dan melihat data stok obat

e. Apoteker dapat melakukan transaksi penjualan baik untuk penjualan umum dan resep penjualan.

f. Apoteker dapat memasukkan pengembalian ramuan non-obat jika dikembalikan oleh pembeli.

g. Apoteker dapat mengelola kamus obat.

h. Apoteker dapat memeriksa kembali jika terjadi kesalahan pembelian obat.

1.2 Kebutuhan Sistem

\subsubsection{Kebutuhan Fungsional}

\section{Kebutuhan Fungsional untuk administrator}

a. Sistem dapat mengelola data pengguna seperti melihat, menambah, mengedit, dan menghapus data pengguna.

b. Sistem dapat melihat dan mengunduh laporan.

Kebutuhan fungsional untuk pegawai gudang

a. Sistem dapat menampilkan dan melakukan fungsi tambah, ubah dan hapus data supplier.

b. Sistem dapat melakukan fungsi tambah dan menampilkan daftar obat dalam penyediaan obat.

c. Sistem dapat melakukan fungsi edit dan menampilkan harga obat.

d. Sistem dapat menampilkan dan melakukan fungsi menambah, mengedit, dan menghapus data master (data obat, tipe data obat). 
e. Sistem ini dapat menampilkan data stok obat.

Kebutuhan fungsional untuk apoteker

a. Sistem dapat melakukan fungsi untuk transaksi penjualan umum.

b. Sistem ini dapat melakukan fungsi untuk penjualan obat-obatan campuran.

c. Sistem dapat melakukan fungsi untuk mengembalikan obat

d. Sistem dapat melakukan fungsi menambah dan mengedit kamus obat.

e. Sistem dapat melakukan fungsi untuk memeriksa pembeli.

1.2.2 Kebutuhan Non-Fungsional

Sistem informasi farmasi berbasis web menggunakan css bootstrap untuk merancang antarmuka pengguna sistem. Menggunakan framework CogeIgniter 3.0 sebagai sistem inti. Sistem ini dapat diakses menggunakan browser internet dengan waktu buka kurang dari 1 menit. Perhitungan dosis akan menggunakan aturan perhitungan dosis dengan rumus Fried and Clark, Young, Dilling dan Thermic.

\section{Rancangan Sistem}

2.1 Activity Design

Activity diagram digunakan untuk menggambarkan aliran kegiatan yang dilakukan oleh pengguna ke sistem informasi farmasi yang dikembangkan

\subsection{Data Design}

Desain data adalah tahap dalam mentransformasikan model data yang dihasilkan dari proses analisis ke dalam struktur basis data yang siap digunakan pada tahap pemrograman. Model database digambarkan dalam ERD, dan kemudian memetakan entitas dalam bentuk tabel pemetaan, dan akhirnya membuat struktur tabel.

\subsection{User Interface Design}

Desain antarmuka pengguna dibuat berdasarkan jenis sistem pengguna, seperti administrator, petugas gudang, dan apoteker.

\section{Implementasi}

Sistem informasi farmasi dikembangkan menggunakan PHP Framework CodeIgniter. Berikut ini adalah implementasi sistem berdasarkan jenis pengguna:

3.1 Halaman Login

Gambar 1 adalah halaman login untuk pengguna, seperti admin, apoteker, dan petugas gudang. Halaman login adalah tahap awal yang dilakukan oleh pengguna sebelum memasuki halaman dashboard sesuai dengan izin.

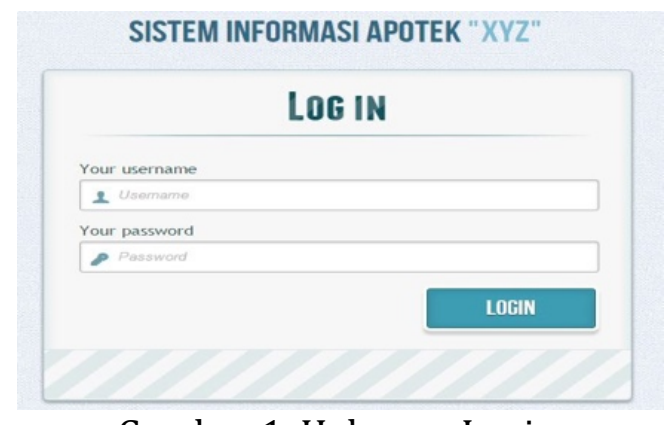

Gambar 1. Halaman Login 
3.2 Halaman Dashboard

Halaman dasbor adalah halaman administrasi untuk mengelola pengguna dan hak akses, seperti menambah, mengedit, dan menghapus pengguna seperti yang ditunjukkan pada Gambar 2. Halaman ini juga dapat mengakses halaman ke pengguna lain.

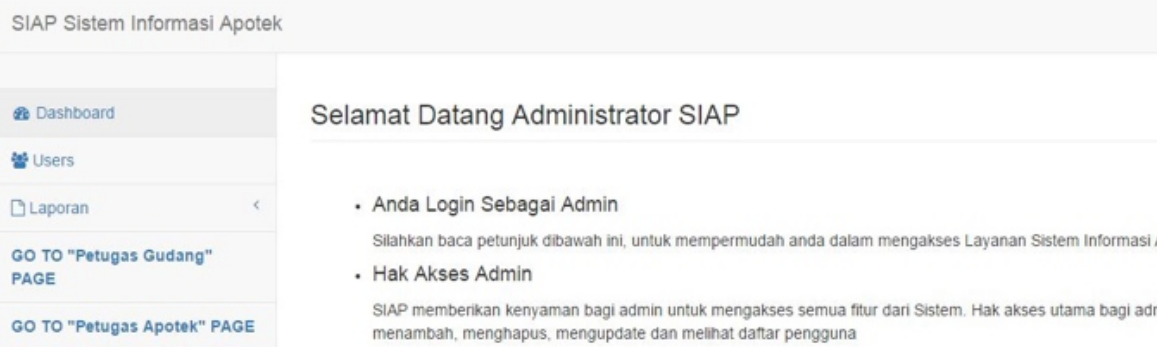

Gambar 2. Dashboard Admin

Manajemen pengguna adalah salah satu hak istimewa untuk admin, seperti yang ditunjukkan pada Gambar 3. Admin dapat menambah, mengedit, dan menghapus setiap pengguna data.

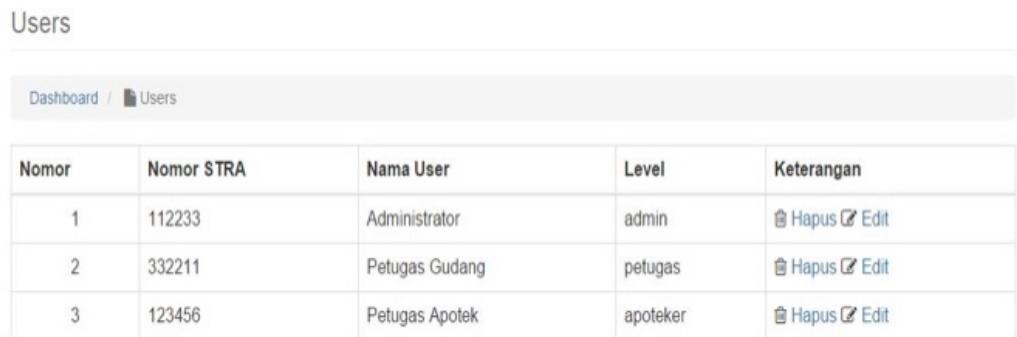

Tambah User

Gambar 3. Halaman manajemen pengguna

3.3 Implementasi antarmuka untuk petugas gudang

Petugas gudang diberikan akses untuk mengelola data di apotek, seperti stok obat, data obat, tipe data obat, dll. Gambar 4 adalah dasbor untuk petugas gudang.

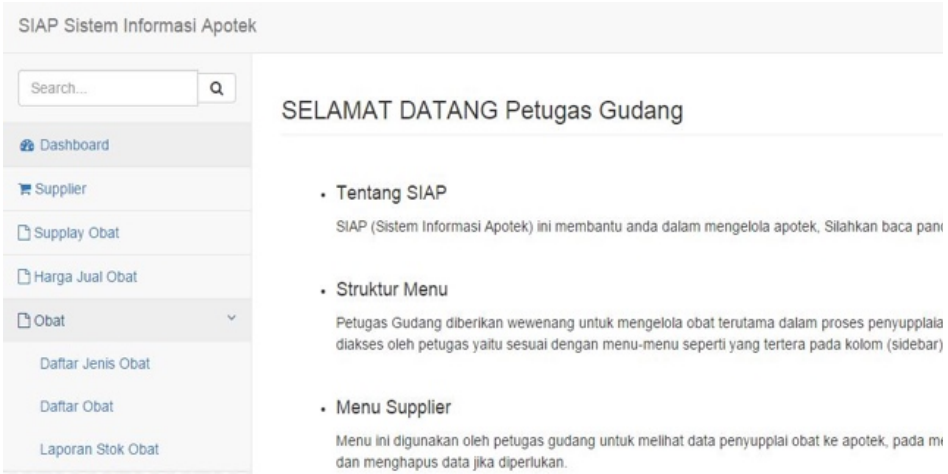

Gambar 4. Halaman dashboard petugas Gudang

Gambar 5 adalah persediaan halaman obat-obatan yang digunakan oleh petugas gudang untuk mencatat obat-obatan yang dipasok oleh pemasok ke apotek. 
Mendokumentasikan obat dalam persediaan adalah salah satu tugas dari petugas gudang, untuk mengisi data barang dalam persediaan, akan membantu dalam pengeluaran dan pendapatan apotek.

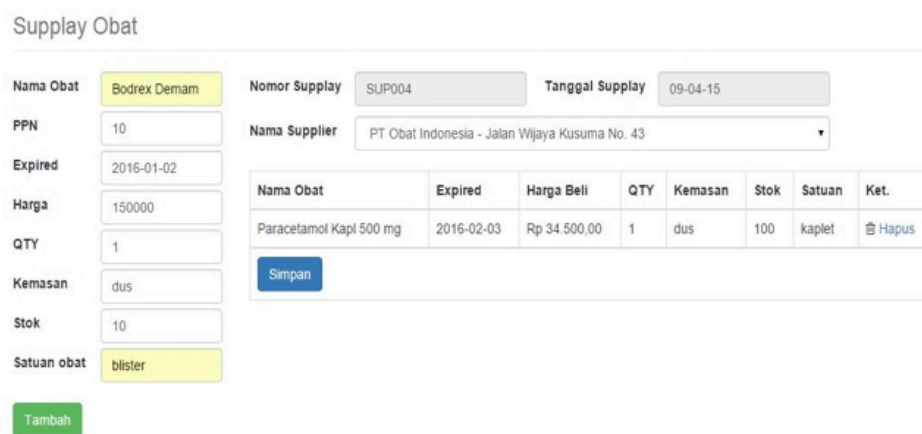

Gambar 5. Halaman pasokan obat

3.4 Implementasi antarmuka untuk apoteker

Apoteker memiliki akses ke penjualan dan pembelian obat-obatan di apotek. Gambar 6 adalah halaman penjualan obat oleh pembeli publik untuk penjualan obat gratis. Selain dapat menjual kepada pembeli publik, Gambar 7, 8, dan 9 adalah serangkaian pandangan untuk penjualan obat resep dalam bentuk peracikan. Gambar 7 adalah halaman input data pembeli, formulir diisi oleh apoteker sebagai catatan medis pembeli, selain berfungsi sebagai salah satu penentu untuk menghitung dosis maksimum yang harus diberikan kepada pembeli berdasarkan usia dan berat badan.

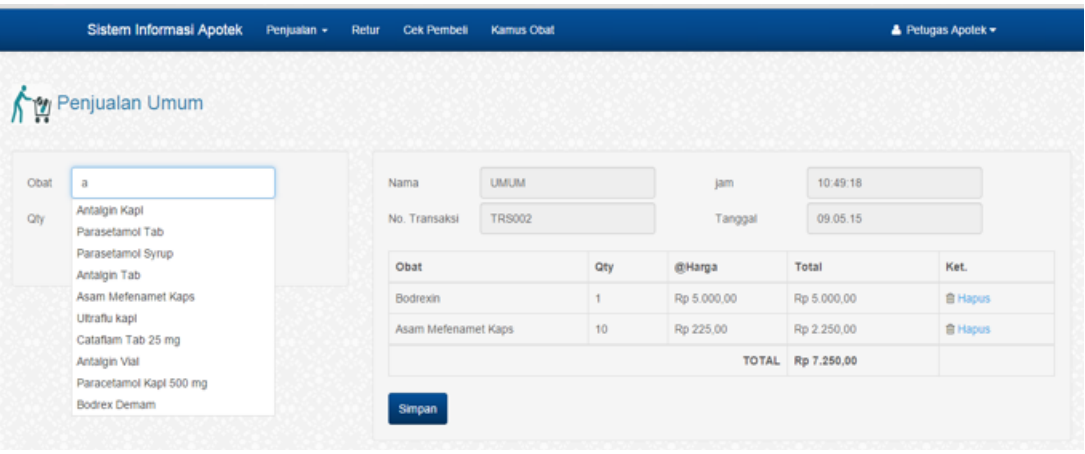

Gambar 6. Halaman penjualan obat umum

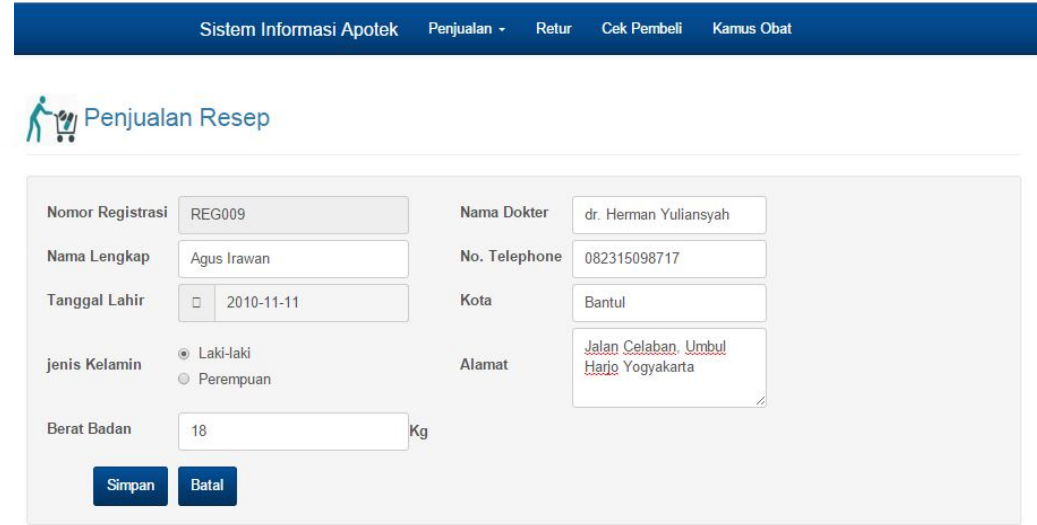

Gambar 7. Halaman input data pembeli obat resep 
Setelah mengisi data pembeli, klik simpan dan proseskan dengan mengisi halaman data untuk obat yang dibeli seperti yang ditunjukkan pada Gambar 8. Data resep dosis dan sistem hasil perhitungan dosis maksimum yang harus diberikan kepada pembeli akan dibandingkan. Jika dosis yang diberikan dokter melebihi informasi dosis maksimum, akan terlihat bahwa obat tersebut tidak dapat diformulasikan.

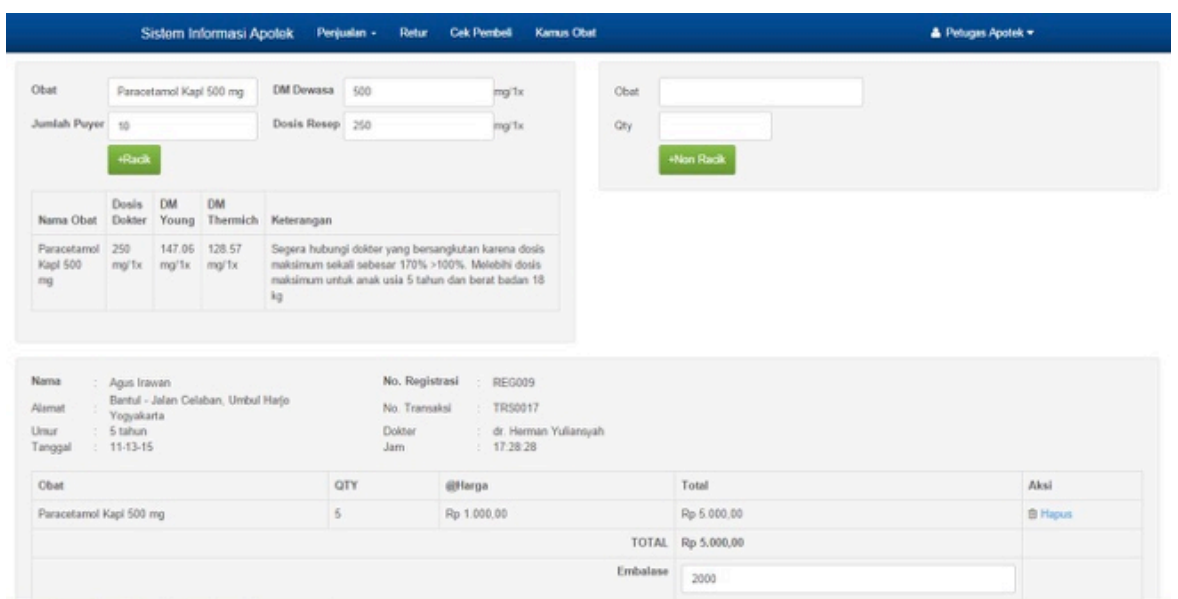

Gambar 8. Halaman input Obat

Jika apoteker tidak mengurangi dosis, dan melanjutkan transaksi, maka sistem akan mengeluarkan peringatan dalam bentuk halaman konfirmasi seperti yang ditunjukkan pada Gambar 9.

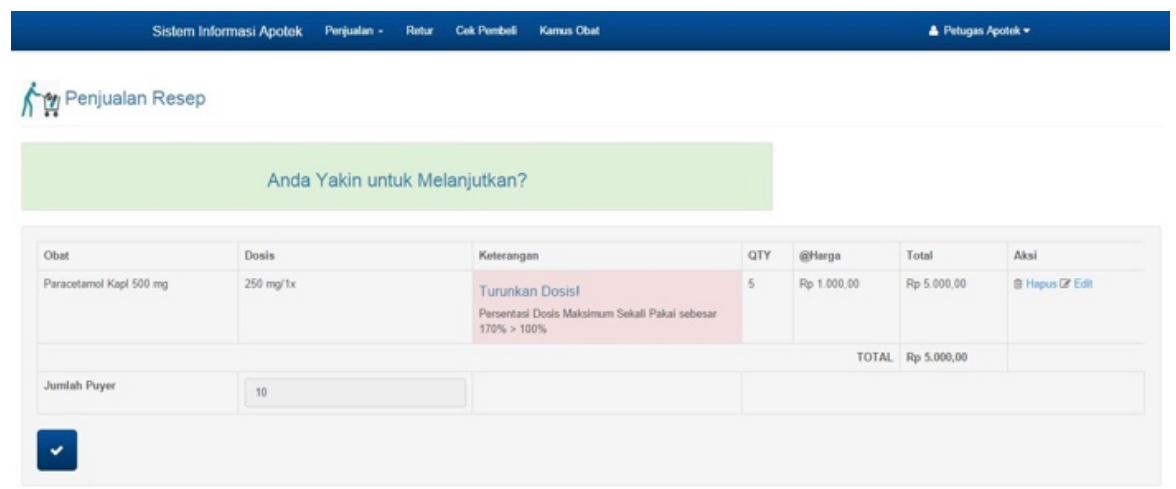

Gambar 9. Halaman konfirmasi

\section{Pengujian Sistem}

4.1 Black Box Test

Black Box Test adalah tes untuk memastikan bahwa fungsi aplikasi telah berjalan sesuai dengan algoritma yang diinginkan. Tabel 1 berikut ini adalah hasil dari pengujian black box sistem informasi farmasi yang dibangun:

Tabel 1. Black Box Testing

\begin{tabular}{lllll}
\hline Tes ID & $\begin{array}{l}\text { Nama Fungsi// } \\
\text { Proses }\end{array}$ & Deskripsi & $\begin{array}{l}\text { Hasil yang } \\
\text { diharapkan }\end{array}$ & $\begin{array}{l}\text { Hasil yang } \\
\text { sebenarnya }\end{array}$ \\
\hline $\mathbf{1}$ & Login & $\begin{array}{l}\text { Persyaratan: Nama } \\
\text { pengguna dan Kata } \\
\text { Sandi salah }\end{array}$ & $\begin{array}{l}\text { Sistem } \\
\text { memberikan } \\
\text { peringatan } \\
\text { kesalahan }\end{array}$ & true \\
& & & \multicolumn{2}{c}{ Nama } \\
\hline
\end{tabular}


Pengguna dan Kata

Sandi

\begin{tabular}{|c|c|c|c|c|}
\hline & & $\begin{array}{l}\text { Persyaratan: Nama } \\
\text { pengguna dan Kata } \\
\text { Sandi sudah benar }\end{array}$ & & \\
\hline & & $\begin{array}{l}\text { Persyaratan: } \\
\text { Login dengan } \\
\text { administrator nama } \\
\text { pengguna dan kata } \\
\text { sandi }\end{array}$ & $\begin{array}{l}\text { Pengguna akan } \\
\text { masuk ke aplikasi } \\
\text { atau halaman } \\
\text { utama - admin } \\
\text { (dashboard) }\end{array}$ & true \\
\hline & & $\begin{array}{l}\text { Persyaratan: } \\
\text { Login dengan nama } \\
\text { pengguna dan kata } \\
\text { sandi petugas gudang }\end{array}$ & $\begin{array}{l}\text { Pengguna akan } \\
\text { masuk ke aplikasi } \\
\text { atau halaman } \\
\text { utama } \\
\text { (dashboard) } \\
\text { petugas gudang }\end{array}$ & true \\
\hline & & $\begin{array}{l}\text { Persyaratan: } \\
\text { Masuk dengan nama } \\
\text { pengguna dan kata } \\
\text { sandi apoteker Anda }\end{array}$ & $\begin{array}{l}\text { Pengguna akan } \\
\text { masuk ke aplikasi } \\
\text { atau halaman } \\
\text { utama } \\
\text { (dashboard) } \\
\text { apoteker }\end{array}$ & true \\
\hline \multirow[t]{9}{*}{2} & Menu Users & Select menu Users & $\begin{array}{l}\text { Menampilkan } \\
\text { daftar pengguna }\end{array}$ & true \\
\hline & Tambah User & Klik add button user & $\begin{array}{l}\text { Menampilkan } \\
\text { formulir input } \\
\text { pengguna }\end{array}$ & true \\
\hline & & Klik tombol simpan & & true \\
\hline & & $\begin{array}{l}\text { Persyaratan: Form } \\
\text { input tidak diisi } \\
\text { semua }\end{array}$ & $\begin{array}{l}\text { Muncul peringatan } \\
\text { formulir validasi } \\
\text { yang belum diisi }\end{array}$ & true \\
\hline & Edit User & $\begin{array}{l}\text { Pilih tautan edit pada } \\
\text { kolom komentar }\end{array}$ & $\begin{array}{l}\text { Menampilkan } \\
\text { formulir edit } \\
\text { pengguna }\end{array}$ & true \\
\hline & & Klik tombol simpan & $\begin{array}{l}\text { Memperlihatkan } \\
\text { halaman daftar } \\
\text { pengguna dengan } \\
\text { perubahan data }\end{array}$ & true \\
\hline & & Klik tombol cancel & $\begin{array}{lr}\text { Kembali } & \text { ke } \\
\text { halaman } & \text { daftar } \\
\text { pengguna } & \end{array}$ & true \\
\hline & Hapus Users & $\begin{array}{l}\text { Pilih tautan hapus } \\
\text { pada kolom } \\
\text { komentar }\end{array}$ & $\begin{array}{l}\text { Menampilkan } \\
\text { pemberitahuan } \\
\text { "Anda yakin akan } \\
\text { menghapus?" }\end{array}$ & true \\
\hline & & Klik OK & $\begin{array}{l}\text { Halaman yang } \\
\text { ditampilkan }\end{array}$ & true \\
\hline
\end{tabular}




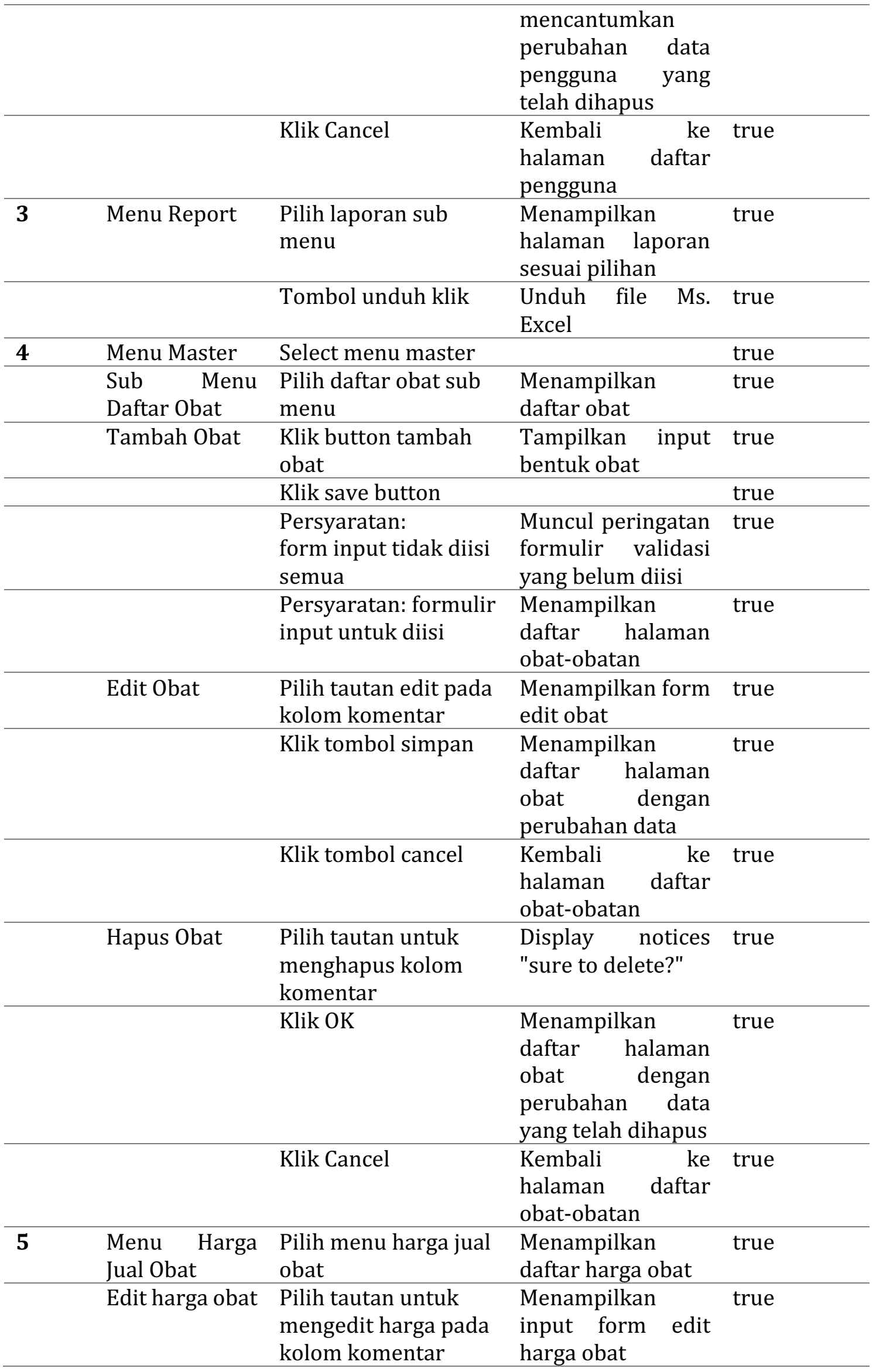




\begin{tabular}{|c|c|c|c|c|}
\hline & & Klik tombol simpan & $\begin{array}{l}\text { Menampilkan } \\
\text { daftar harga } \\
\text { halaman dengan } \\
\text { perubahan data }\end{array}$ & true \\
\hline & & Klik tombol cancel & $\begin{array}{lr}\text { Kembali } & \text { ke } \\
\text { halaman } & \text { daftar } \\
\text { harga obat } & \end{array}$ & true \\
\hline \multirow[t]{4}{*}{6} & $\begin{array}{l}\text { Menu supplay } \\
\text { obat }\end{array}$ & $\begin{array}{l}\text { Pilih menu supplay } \\
\text { obat }\end{array}$ & $\begin{array}{l}\text { Menampilkan } \\
\text { halaman supplay } \\
\text { obat }\end{array}$ & true \\
\hline & & $\begin{array}{l}\text { Mengisi form supplay } \\
\text { obat }\end{array}$ & $\begin{array}{l}\text { Fungsi } \\
\text { autocomplete aktif }\end{array}$ & true \\
\hline & & Klik button tambah & $\begin{array}{l}\text { Memindahkan } \\
\text { data pada table } \\
\text { daftar supplay }\end{array}$ & true \\
\hline & & Klik button simpan & \begin{tabular}{ll}
\multicolumn{2}{l}{ Menampilkan } \\
notifikasi data \\
yang & telah \\
disimpan &
\end{tabular} & true \\
\hline \multirow[t]{11}{*}{7} & Menu Supplier & Pilih menu Supplier & & true \\
\hline & $\begin{array}{l}\text { Tambah } \\
\text { Supplier }\end{array}$ & $\begin{array}{l}\text { Klik button tambah } \\
\text { Supplier }\end{array}$ & $\begin{array}{l}\text { Menampilkan form } \\
\text { input supplier }\end{array}$ & true \\
\hline & & Klik button simpan & & \\
\hline & & $\begin{array}{l}\text { Syarat : form input } \\
\text { tidak diisi }\end{array}$ & $\begin{array}{l}\text { Muncul peringan } \\
\text { form validasi yang } \\
\text { belum diisi }\end{array}$ & true \\
\hline & & $\begin{array}{l}\text { Syarat : form input } \\
\text { diisi semua }\end{array}$ & $\begin{array}{l}\text { Menampilkan } \\
\text { halaman daftar } \\
\text { supplier }\end{array}$ & true \\
\hline & Edit Supplier & $\begin{array}{l}\text { Pilih link edit pada } \\
\text { kolom keterangan }\end{array}$ & $\begin{array}{l}\text { Menampilkan form } \\
\text { edit supplier }\end{array}$ & true \\
\hline & & Klik button simpan & $\begin{array}{l}\text { Menampilkan } \\
\text { halaman daftar } \\
\text { supplier dengan } \\
\text { perubahan data }\end{array}$ & true \\
\hline & & Klik button Batal & $\begin{array}{l}\text { Mereset form } \\
\text { supplier }\end{array}$ & true \\
\hline & Hapus Supplier & $\begin{array}{l}\text { Pilih link hapus pada } \\
\text { kolom keterangan }\end{array}$ & $\begin{array}{l}\text { Menampilkan notif } \\
\text { "yakin } \\
\text { menghapus?" }\end{array}$ & true \\
\hline & & Klik OK & \begin{tabular}{lr}
\multicolumn{2}{l}{ Menampilkan } \\
halaman daftar \\
supplier dengan \\
perubahan \\
yang & data \\
dihapus & \\
\end{tabular} & true \\
\hline & & Klik Cancel & $\begin{array}{lr}\text { Kembali } & \text { ke } \\
\text { halaman } & \text { daftar } \\
\text { supplier } & \end{array}$ & true \\
\hline
\end{tabular}




\begin{tabular}{|c|c|c|c|c|}
\hline & & $\begin{array}{l}\text { Syarat : Login sebagai } \\
\text { Apoteker }\end{array}$ & & \\
\hline \multirow[t]{12}{*}{8} & $\begin{array}{l}\text { Menu } \\
\text { Penjualan }\end{array}$ & Pilih menu penjualan & $\begin{array}{l}\text { Menampilkan } \\
\text { submenu } \\
\text { penjualan }\end{array}$ & true \\
\hline & $\begin{array}{l}\text { Submenu } \\
\text { Umum }\end{array}$ & Pilih umum & $\begin{array}{l}\text { Menampilkan } \\
\text { halaman penjualan } \\
\text { obat untuk umum }\end{array}$ & true \\
\hline & & $\begin{array}{l}\text { Mengisi form } \\
\text { penjualan umum }\end{array}$ & $\begin{array}{ll}\text { Input } & \text { obat } \\
\text { autocomplite } & \end{array}$ & true \\
\hline & & Klik tambah & $\begin{array}{l}\text { Memindahkan } \\
\text { data obat yang } \\
\text { ditambah pada } \\
\text { form } \\
\text { pembelian }\end{array}$ & true \\
\hline & & Klik simpan & Mencetak struk & true \\
\hline & $\begin{array}{l}\text { Submenu } \\
\text { Resep }\end{array}$ & Pilih resep & $\begin{array}{l}\text { Menampilkan form } \\
\text { pembeli }\end{array}$ & true \\
\hline & & Klik button simpan & & true \\
\hline & & $\begin{array}{l}\text { Syarat : form input } \\
\text { tidak diisi }\end{array}$ & $\begin{array}{l}\text { Muncul peringan } \\
\text { form validasi yang } \\
\text { belum diisi }\end{array}$ & true \\
\hline & & $\begin{array}{l}\text { Syarat: form input } \\
\text { diisi semua }\end{array}$ & $\begin{array}{l}\text { Menampilkan } \\
\text { halaman } \\
\text { pembelian resep }\end{array}$ & true \\
\hline & & $\begin{array}{l}\text { Mengisi form input } \\
\text { obat }\end{array}$ & $\begin{array}{l}\text { Autocomplite obat } \\
\text { active }\end{array}$ & true \\
\hline & & Klik +racik & $\begin{array}{l}\text { Menambahkan } \\
\text { obat ke tabel daftar } \\
\text { pembelian, muncul } \\
\text { informasi dosis } \\
\text { dan keterangan } \\
\text { peracikan. }\end{array}$ & true \\
\hline & & Klik simpan & $\begin{array}{lr}\text { Mencetak } & \text { struk } \\
\text { pembelian } & \text { obat } \\
\text { resep } & \end{array}$ & true \\
\hline \multirow[t]{5}{*}{9} & Menu Retur & Pilih menu retur & $\begin{array}{l}\text { Menampilkan } \\
\text { halaman retur }\end{array}$ & true \\
\hline & & $\begin{array}{l}\text { Input nomor } \\
\text { transaksi }\end{array}$ & & true \\
\hline & & $\begin{array}{l}\text { Syarat: input nomor } \\
\text { transaksi salah }\end{array}$ & $\begin{array}{lr}\text { Muncul } & \text { notifikasi } \\
\text { data } & \text { tidak } \\
\text { ditemukan } & \end{array}$ & true \\
\hline & & $\begin{array}{l}\text { Syarat : input nomor } \\
\text { transaksi }\end{array}$ & $\begin{array}{l}\text { Muncul daftar obat } \\
\text { yang dibeli }\end{array}$ & true \\
\hline & & Klik link retur & $\begin{array}{l}\text { Menghapus daftar } \\
\text { obat yang dibeli }\end{array}$ & true \\
\hline
\end{tabular}




\begin{tabular}{|c|c|c|c|c|}
\hline 10 & Cek Pembeli & $\begin{array}{l}\text { Pilih menu cek } \\
\text { pembeli }\end{array}$ & $\begin{array}{l}\text { Menampilkan } \\
\text { halaman } \\
\text { pembeli }\end{array}$ & true \\
\hline & & $\begin{array}{l}\text { Input nomor } \\
\text { registrasi }\end{array}$ & & true \\
\hline & & $\begin{array}{l}\text { Syarat: input nomor } \\
\text { transaksi salah }\end{array}$ & $\begin{array}{lr}\text { Muncul } & \text { notifikasi } \\
\text { data } & \text { tidak } \\
\text { ditemukan } & \end{array}$ & true \\
\hline & & $\begin{array}{l}\text { Syarat: input nomor } \\
\text { transaksi }\end{array}$ & $\begin{array}{l}\text { Muncul informasi } \\
\text { pembeli dan obat } \\
\text { yang dibeli }\end{array}$ & true \\
\hline \multirow[t]{2}{*}{11} & Kamus Obat & $\begin{array}{l}\text { Pilih menu kamus } \\
\text { obat }\end{array}$ & $\begin{array}{l}\text { Menampilkan } \\
\text { halaman kamus } \\
\text { obat }\end{array}$ & true \\
\hline & & Klik link edit & $\begin{array}{l}\text { Menampilkan } \\
\text { deksripsi obat } \\
\text { yang di edit }\end{array}$ & true \\
\hline
\end{tabular}

4.2 Pertanyaan Terbuka

Pertanyaan terbuka adalah teknik pengujian sistem dengan mengajukan pertanyaan yang terbuka. Ini untuk mengetahui tentang aplikasi yang dibangun telah mampu memproses perhitungan dosis sesuai dengan aturan perhitungan yang ada. Hasil pengujian diperoleh bahwa aplikasi yang telah dibangun sudah sesuai dengan kebutuhan pengguna dan prosedur peracikan, dan informasi dosis yang diberikan sesuai dengan perhitungan dosis yang ada.

\section{KESIMPULAN}

Berdasarkan hasil dan diskusi, dapat disimpulkan bahwa penelitian ini telah mengembangkan sistem informasi farmasi berbasis web dengan menggunakan konsep MVC yang dapat menangani proses penjualan obat-obatan peracikan dan nonperacikan. Sistem ini memiliki fungsi deteksi kesalahan obat untuk membantu perhitungan dosis dalam pengobatan peracikan. Berdasarkan pengujian sistem, bahwa semua fungsi dalam sistem ini sudah bekerja dengan baik, dan perhitungan obat peracikan sudah sesuai dengan perhitungan dosis yang dimaksud.

\section{DAFTAR PUSTAKA}

[1] Kementrian Kesehatan RI, "Peraturan Menteri Kesehatan RI No. 1027/Menkes/SK/IX/2004 tentang standar pelayanan kefarmasian." 2004.

[2] Rusmi Sari Tajuddin, Insritanty Sudirman, and Alimin Maidin, "Faktor Penyebab Medication Error di Instalasi Rawat Darurat," Jurnal Manajemen Pelayanan Kesehatan, vol. Vol.15 No. 04, 2012.

[3] Tri Murwanto, Wahyul Amien Syafei, and R. Rizal Isnanto, "Rancang Bangun Sistem Informasi Apotek Berbasis Web," Transient, vol. 2302-9927, 582 Vol. 2 No. 3, 2013.

[4] Muhammad Azhar Irwansyah and Dessy Kartika Kresna, "Rancang Bangun Sistem Informasi Manajemen Apotek Berbasis Client Server,” J. ELKHA, vol. Vol. 2, No.2, 2012. 
[5] Cecep Lupi Hepyan, Erwin Gunadhi, and Rina Kurniawati, "Rekayasa Perangkat Lunak Aplikasi Penjualan Obat pada Apotek Mulya Abadi," vol. 2302-7339 Vol.9 No.43, 2012.

[6] Hanik Mujiati, Bambang Eka Purnama, and Sukadi, "Pembangunan Sistem Informasi Persediaan Obat pada Apotek Arjowinangun,” IJCSS, vol. 1979-9330, 2013.

[7] Nurdiansyah and Ramadian Agus Triyono, "Pembuatan Sistem Informasi Apotek Berbasis Web pada Apotek Tulakan,” IJNS - Indones. J. Netw. Secur., vol. 23025700 Vol.2 No.3, 2013.

[8] Mashuda, A., Standar Kompetensi Apoteker Indonesia. Jakarta: Pengurus Ikatan Apoteker Indonesia, 2011.

[9] Mohamed Aslam and Chik Kaw Tan, Farmasi Klinis (Clinical Pharmacy), Menuju Pengobatan Rasional dan Penghargaan Pilihan Pasien. Jakarta: Alex Media Komputindo, 2003.

[10] Moh. Anief, Ilmu Meracik Obat Teori dan Praktik. Yogyakarta: Gadjah Mada University Press, 1999. 